\title{
A SURGICAL AND BIOCHEMICAL STUDY OF A CASE OF BILATERAL HYDRONEPHROSIS AND HORSESHOE KIDNEY
}

\author{
BY \\ JOHN BLACK and JOAN WAGNER \\ From The Hospital for Sick Children, Great Ormond Street, London
}

(RECEIVED FOR PUBLICATION NOVEMBER 2, 1954)

Congenital abnormalities of the kidney are often symptomless and may be discovered on routine investigation of minor urinary disorders. Such kidneys are, however, very susceptible to pathological change and have been described in association with every form of renal disease. A horseshoe kidney is the commonest form of fused kidney and is often associated with hydronephrosis of one or both sides. The hydronephrosis is usually attributed to kinking of the ureter by bands or vessels and occasionally to compression of the ureter as it passes over the isthmus. The important pathological point is how much damage is done by the hydronephrosis to the renal tissue, as the nephrons can be damaged both by back pressure and by interference with their blood supply. The extent of the obstruction and superadded infection will have bearing on how great this damage is.

Such lesions may be asymptomatic or give rise to a variety of symptoms. The commonest are failure of growth, abdominal pain, and symptoms related to micturition. In many cases there is a palpable abdominal mass. If both halves of the kidney are functioning normally intravenous pyelography will give the diagnosis in almost every case. If hydronephrosis has suppressed function on one side a malrotation of the other side may be diagnosed. Retrograde pyelography should, however, provide the true answer.

The treatment, if possible, should consist of relieving obstruction and preserving the kidneys. In simple hydronephrosis the results are excellent, but in the case of a horse-shoe kidney with unior bi-lateral hydronephrosis the position is more difficult since probably neither side is functioning normally. It is therefore essential to find out as far as possible what function is present on either side. Surgery must be conservative in these cases, but can produce a great deal of benefit.
The case presented here showed several points of interest. The diagnosis was fairly simple but illustrates some of the points mentioned above. Biochemical studies of the urine produced by the two halves of the patient's kidney were puzzling but extremely interesting, and we will attempt to explain them. It is far too early to say what the child's future will be, but the results of surgical treatment are, at least during the first year afterwards, very impressive.

\section{Case Report}

The patient, a girl, was admitted to hospital at the age of 6 months, on November 9, 1953. Her mother complained that she failed to thrive. Her birth weight had been $6 \mathrm{lb} .2 \mathrm{oz}$., and at 10 days of age she had regained this weight. One week later she became 'grizzly' and started to lose weight. At 5 weeks she weighed $5 \mathrm{lb} .8 \mathrm{oz}$. and from then until the time of admission, when she weighed $10 \mathrm{lb}$., she had gained extremely slowly, often having periods of loss. She had vomited very occasionally, but had no other symp.oms. She was breast fed for six weeks, and then was put on National dried milk. Adequate amounts had always been offered to her but she seldom took even half the feed.

Her mother was quite well during her full-term pregnancy and the birth was quite normal. She had a healthy brother of 5 years, and both parents were quite well. Her paternal grandfather and an uncle died of tuberculosis, but many years before her birth, and the father on several occasions had a negative chest radiograph.

On examination the baby weighed $10 \mathrm{lb}$. and was $23 \frac{1}{4}$ in. long. Her temperature was $102^{\circ}$. Her blood pressures were: right arm 180/80, left arm 190/120, right leg $170 / 110$, left leg $190 / 40 \mathrm{~mm}$. Hg. There was a loud systolic murmur, maximal in the fourth left interspace. The abdomen was distended, and in the left hypochondrium and lower abdomen a large cystic mass could be felt. There were no other abnormal signs.

A blood count gave: red cells 3,620,000, haemoglobin $76 \%$ (10.6 g.), white cells 11,000 (63\% neutrophils, $37 \%$ lymphocytes), E.S.R., $30 \mathrm{~mm}$. 
No albumin or pus cells were found in the urine which was sterile on culture.

A blood culture was negative.

The Mantoux test (1:100) was negative.

A chest radiograph was normal, and no abnormality was shown in a straight radiograph of the abdomen.

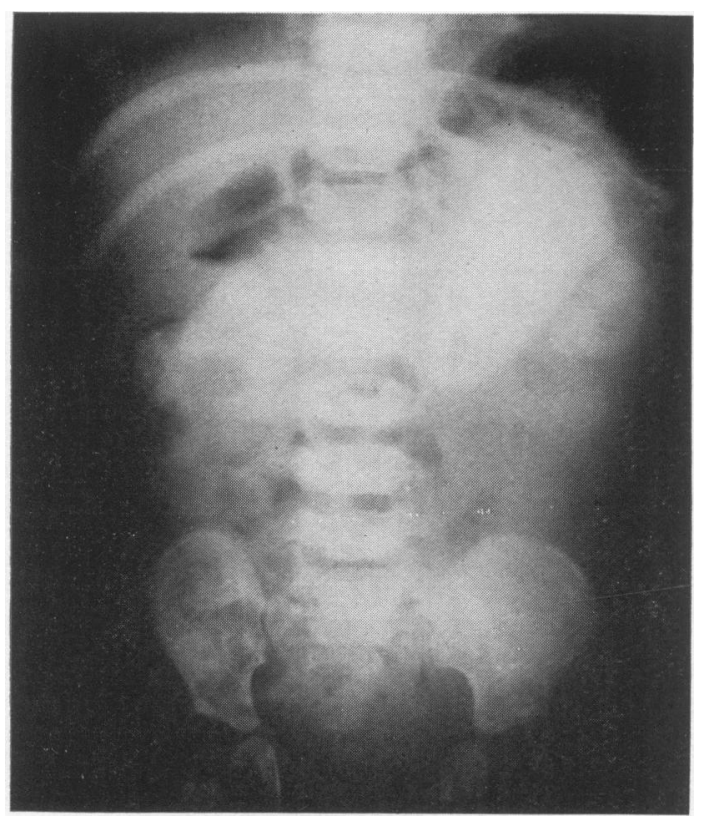

Fig. 1.-Intravenous pyelogram.
Blood analyses gave: Urea $84 \mathrm{mg}$. per $100 \mathrm{ml}$., phosphorus $3.3 \mathrm{mg}$. per $100 \mathrm{ml}$, calcium $10.6 \mathrm{mg}$. per $100 \mathrm{ml}$., bicarbonate 37.5 vol. per $100 \mathrm{ml}$., sodium $308 \mathrm{mg}$. per $100 \mathrm{ml}$., potassium $19.0 \mathrm{mg}$. per $100 \mathrm{ml}$., chlorides $611 \mathrm{mg}$. per $100 \mathrm{ml}$, and total proteins $6 \cdot 71 \%$ (albumin $3 \cdot 29 \%$, globulin $3 \cdot 42 \%$ ).

An intravenous pyelogram showed bilateral hydronephrosis, more marked on the left side.

A series of chemotherapeutic and antibiotic drugs was tried with no effect on the patient's persistent temperature. Excessive hydration both orally and intravenously was similarly ineffectual. However, her general condition remained good, and surgical exploration was decided upon in spite of her fever. The intravenous pyelogram showed hydronephrosis without indicating the site of the obstruction (Fig. 1) but clinically the swellings were so low in the abdomen that it was thought that the ureters must be dilated. In view of the temperature and severity of the obstruction it was considered that preliminary drainage of the kidneys was desirable. Bilateral pyelostomy was therefore performed, with an interval of four days between the two sides, the operations being undertaken through small incisions which did not fully expose the kidneys.

Urine was collected and analysed from both sides.

Two weeks later cystoscopy was carried out and the bladder found to be normal. Pyelograms performed by injecting 'pyelosil' into the pyelostomy tubes did not give any clear indication of the site of the obstruction (Figs. 2 and 3), and exploratory operation was therefore undertaken. The lower ends of the ureters were exposed, but both found to be normal. On tracing them upwards the isthmus of a horseshoe kidney was discovered and the obstruction was evidently at the pelvi-ureteric junc-

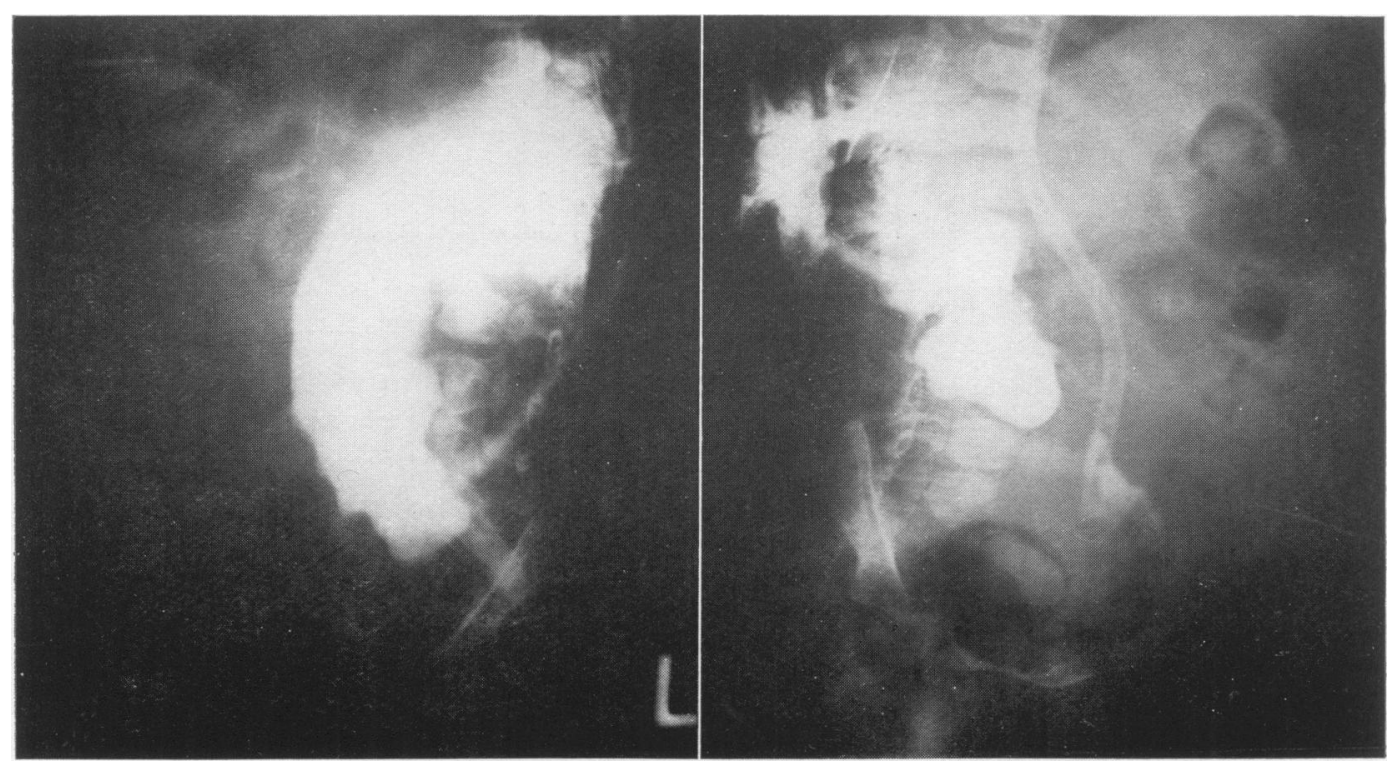

FIGs. 2 and 3.-Left (Fig. 2) and right (Fig. 3) pyelograms through pyelostomy tubes. 
tion. On the left side no cause of obstruction was found, but a side-to-side anastomosis between the pelvis and ureter was made. The right ureter showed a stenosed area $1 \mathrm{~cm}$. long running antero-laterally, immediately below the pelvis. This was excised and the upper end of the ureter split longitudinally and re-anastomized to the pelvis.

Both sides were drained for eight days post-operatively.

Her subsequent course was very satisfactory. Her temperature returned to normal, though occasionally fluctuating. She took her food more readily, and gained weight fairly well. She developed a mild urinary infection three months after the last operation, but this settled after a course of sulphafurazole.

She was last seen seven months after the final operation and was extremely well; her weight was $15 \mathrm{lb} .4 \mathrm{oz}$. The urine and blood pressure were normal, and the blood urea concentration $42 \mathrm{mg}$. \% .

\section{Pre- and Post-operative Changes in Blood and Urine Chemistry}

Before operation (L. nephrostomy) the blood urea was slightly raised (84 mg.\%) and there was a moderate degree of acidosis with a low serum sodium level. The serum potassium level was normal (19 mg. \%). During the pre-operative period there was a slight fall in blood urea so that on the day before the left nephrostomy was performed the figure had fallen to $52 \mathrm{mg}$. \%.

During the three days after the first (left) nephrostomy, there was no further drop in blood urea, but a definite fall in serum potassium and a slight rise in serum sodium, changes which are commonly seen in post-operative patients. With the rise in serum sodium there was a corresponding rise in the bicarbonate level.

During the few days after the second (right) nephrostomy there were similar changes. The cystoscopy on December 4 produced the same type of effect.

An analysis of the urinary output collected from each kidney separately produced some puzzling results. It
TABLE 1

BLOOD FINDINGS

\begin{tabular}{|c|c|c|c|c|c|}
\hline Date & $\begin{array}{c}\text { Plasma } \\
\text { Bicar- } \\
\text { bonate } \\
\text { (Vols. CO }{ }_{2} \\
\text { per } \\
100 \mathrm{ml} .)\end{array}$ & $\begin{array}{c}\text { Plasma } \\
\text { Chlorides } \\
\text { as } \mathrm{NaCl} \\
\text { (mg./ } \\
100 \mathrm{ml} .)\end{array}$ & $\begin{array}{l}\text { Serum } \\
\text { Sodium } \\
\text { (mg./ } \\
100 \mathrm{ml} .)\end{array}$ & $\begin{array}{c}\begin{array}{c}\text { Serum } \\
\text { Potassium }\end{array} \\
\text { (mg./ } \\
100 \mathrm{ml} .)\end{array}$ & $\begin{array}{c}\begin{array}{c}\text { Blood } \\
\text { Urea }\end{array} \\
\text { (mg./ } \\
100 \mathrm{ml} .)\end{array}$ \\
\hline $\begin{array}{c}\text { Nov., } \\
1953: \\
11 \\
12 \\
17 \\
19 \\
20 \\
23 \\
24 \\
25 \\
29\end{array}$ & $\begin{array}{l}37 \cdot 5 \\
46 \cdot 8 \\
52 \cdot 4 \\
\\
50 \cdot 2 \\
\\
48 \cdot 2 \\
50 \cdot 8\end{array}$ & $\begin{array}{l}611 \\
604 \\
606\end{array}$ & $\begin{array}{c}308 \\
315 \\
\\
\text { nephrost } \\
315 \\
\text { nephros } \\
322 \\
318\end{array}$ & $\begin{array}{l}19 \\
\\
\\
14 \\
16 \\
\\
\\
\\
\\
\\
\text { omy } \\
\\
\\
14 \\
14\end{array}$ & $\begin{array}{l}84 \\
52 \\
51 \\
52 \\
51 \\
76\end{array}$ \\
\hline
\end{tabular}

had been previously noticed after the first nephrostomy that the urinary output from the nephrostomy tube greatly exceeded that from the right kidney, which was passed per urethram. However, it was thought that persisting obstruction to the ureter might account for these findings. After the second (right) nephrostomy there was little change in the volumes produced from each side. The discrepancy between the two sides was indeed very large (see analysis). Initially, the right kidney passed only about $1 / 20$ of the volume produced by the left side.

During the post-operative phase the output from both $\delta \vec{c}$ sides gradually increased, the right side increasing more or rapidly than the left; by the fourth post-operative day the output from the right side was $1 / 6$ that from the left, though the left side had almost doubled its own output. After this the ratio of the volumes of the two sides remained at about $-1: 6$. As far as could be discovered, by the use of dyes, there was no mixing of the urine from the two halves of the horse-shoe kidney.

The biochemical analyses are shown in Tables 1 and 2.

TABLE 2

URINARY FINDINGS




The interpretation of these findings is not easy. It was thought at operation that the right kidney was not only larger than the left but also that it contained more renal substance and had a lesser degree of hydronephrosis than the left side. If this were so, one would expect the right kidney to show greater powers of concentration and a greater ability to vary the composition of the urine passed under different circumstances.

The increase in the output of both kidneys during the late post-operative period presumably reflects partly an increase in fluid intake, with perhaps some improvement in function of the right side after decompression. As judged by the urea and sodium concentrations, the right side was able to vary the urine composition a little more than the left side, which passed throughout the period of observation a urine of almost constant composition.

It seems likely that the left kidney was doing nothing more than acting as a drain for glomerular filtrate. In other words, there was a greater tubular re-absorptive defect than glomerular defect. Since the child was being given very adequate quantities of sodium salts, there would be no necessity for sodium conservation by the right kidney, hence the fairly constant sodium excretion with occasional peaks in concentration. The potassium presents the opposite side of the picture. Here the blood usually showed evidence of potassium depletion but the left kidney continued to pass large amounts, up to nearly $1 \mathrm{~g}$. of potassium daily. It would therefore be necessary for the right side to conserve potassium as far as its damaged capabilities would allow: hence the persistently low potassium concentration in the right side.

Similar considerations probably apply to the differences in fluid output. The left side had a constant polyuria. The reaction of the right kidney would be to pass small quantities of urine, though it is probable that on this side too there was some defect in concentrating power.
Other points in which this case was unusual were the finding of quite a severe degree of hypertension $(190 / 120 \mathrm{~mm} . \mathrm{Hg})$ and also a constant fever which was unaffected by antibiotics. At first it was thought that the fever might be similar to that found in pitressinresistant diabetes insipidus when deprived of water (Luder and Burnett, 1954). But this fever is found with hyperelectrolytaemia and is brought down by giving adequate fluids. In this case, the giving of enormous quantities of fluid had no effect upon the temperature nor was there any hyperelectrolytaemia. It is possible that the fever did, in fact, represent the reaction to a chronic pyelonephrosis, of which the hypertension was also a manifestation. There may have been small areas of infected renal tissue, relatively avascular, and shut off from contact with urine, which would not be adequately treated by antibiotics.

\section{Summary}

The case is described of a baby suffering from bilateral hydronephrosis associated with a horseshoe kidney, and of the surgical treatment given. Detailed studies of urinary output and urinary and blood chemistry in the pre- and post-operative period are given, and an attempt made to explain the changes which occurred. It is felt that the child's chances of normal life are extremely good, though too short a period has passed for any definite prognosis to be given.

We should like to thank Professor Alan Moncrieff, under whose care the child was treated, and Mr. D. I. Williams, who performed the operations, for their permission to publish the case, and Dr. W. W. Payne and Mr. Williams for their helpful criticism in the preparation of this paper.

\section{REFERENCE}

Luder, J. and Burnett, D. (1954). Archives of Disease in Childhood, 29, 44. 